\title{
COVID-19 Pandemi Sürecinde Sağlıklı ve Hasta Bireylerin Konut Deneyimine Dair Bir Karşılaştırma: Antalya Örneği
}

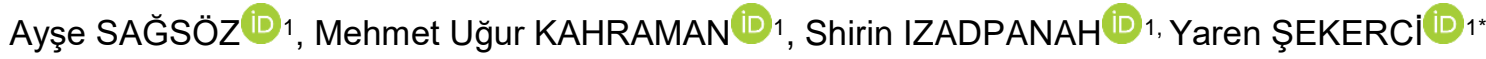 \\ ${ }^{1}$ Antalya Bilim Üniversitesi, Güzel Sanatlar ve Mimarlık Fakültesi, Antalya \\ Geliş Tarihi (Received): 04.02.2021, Kabul Tarihi (Accepted): 14.03.2021 \\ $\square$ Sorumlu Yazar (Corresponding author*): yaren.sekerci@antalya.edu.tr \\ (C) +902422450000 呂 +902422450100
}

öz

Insanlığın kadim sorunlarından biri de "pandemi" olarak adlandırılan salgın ve bulaşıcı hastalıklardır. Dünya Sağlık Örgütü'nün 2019 raporunda tanımlamasına göre, SARS-CoV-2 adı verilen yeni bir koronavirüsün neden olduğu bu son pandemi ise COVID-19 olarak adlandırımıştır. COVID-19, küresel anlamda tüm insanların hayatını etkilemiş ve gündelik hayat rutinlerini değiştirmiştir. Pandemiyle mücadele kapsamında ortak kullanılan alanlarda yapılan faaliyetler kısıtlanırken, çalışma ve eğitim hayatları çevrimiçi ortamlara taşınmıştır. Öğrenci ve çalışan kesimin de faaliyetlerini mümkün olduğunca konut ortamına taşıması, konut içinde çalışmanın önemini arttırırken, konutun işlerliğini de sorgulanır hale getirmektedir. Dışarı çıkma yasaklarının yoğun şekilde yaşandığı ve çeşitli kullanıcı profillerinin farklı sorunları deneyimlediği zorlu pandemi süreci, yapılan bu çalışmaya zemin oluşturmaktadır. Kısıtlamalardan dolayı, anket yöntemiyle Antalya ölçeğinde gerçekleştirilen çalışmada; "konut" kavramına ilişkin söylemlere, bir bakış açısı daha getirilmek istenirken, COVID-19 pandemisi sırasında kronik hasta ve sağlıklı bireylerin konut mekânı deneyimlerinin ayrı ayrı değerlendirildiği bir karşılaştırma yaparak, gündelik deneyimlere dair farklılıkları ve benzerlikleri saptamak amaçlanmaktadır. Bu bağlamda, tümünün sağlıklı olduğu ve en az bir hasta bireyin yaşadığı konutlardaki deneklerin konut deneyimleri karşılaştırılmıştır.

Anahtar Kelimeler: COVID-9, konut, pandemi ve konut, pandemi ve konut mekân deneyimi

\section{A Comparison of the Housing Experience of Healthy and Sick Individuals during COVID-19 Pandemic: The Case Study of Antalya, Turkey}

\begin{abstract}
One of the ancient problems of humanity is epidemic and infectious diseases called "pandemic". According to the World Health Organization's definition in its 2019 report, this last pandemic caused by a new coronavirus called SARS-CoV-2 was named COVID-19. It has affected the lives of many people globally and changed their daily life routines. While the activities in common spaces within the scope of fight against the pandemic were restricted, work and education lives were moved to online environments. The fact that students and employees carried their activities to the home environment as much as possible have been increased the importance of working at home and made its operability questionable. The difficult pandemic period, in which various user profiles experience different problems through intense bans and lockdowns lays the groundwork for this study. In the process which is conducted with the survey method in Antalya scale due to limitations, one more perspective was being tried to brought to the discourses on the concept of "home", while it is aimed to identify the differences and similarities in daily experiences by making a comparison in which the home experience of chronic patients and healthy individuals are evaluated separately during the COVID-19 pandemic. In this context, the housing experiences of the participants in the residential spaces where all of them are healthy and where at least one sick individual lives were compared.
\end{abstract}


Keywords: COVID-19, housing, pandemic and housing, pandemic and residential space experience

\section{GíRiş}

Kıtlık, salgın hastalık ve savaşlar, insanlığın çözümleyemediği temel sorunlardır. İnsanoğlunun hiçbir icadı; bu sorunlardan kaynaklanan kitlesel ölümlere son verememiştir. Genel anlamda "pandemi" (Pandemi: (eski Yunanca: pan: tüm + demos: insanlar), bir kıta gibi çok geniş bir coğrafyaya, ve hatta belli durumlarda bütün dünyaya yayılan salgın hastalıkların genel ismi (Parıldar, 2020) olarak adlandırılan salgın ve bulaşıcı hastalıklar, insanlık tarihinde Ortaçağ'dan beri görülmektedir. Önceki çağlarda tüccar, memur ve seyyahların devamlı sirkülasyonuyla birbirine bağlanan şehirler her ne kadar dönemin şartlarına göre medeniyetin beşiği kabul edilmişse de, hastalıkların üremesi ve yayılması için de ideal ortamı oluşturmuştur. Kara Veba olarak bilinen meşhur salgın, 1348 veba salgını genel kabule göre Asya kıtasından Sicilya yoluyla Avrupa kıtasına geçmiş ve son derece önemli sonuçlara yol açmış bir salgın olup, yirmi yıldan kısa sürede Atlantik Okyanusu'na kadar ulaşmıştır (Özlem, 2011). Milyonlarca insanın ölümüne yol açan bu hastalık, tarihteki tek ya da en kötü bulaşıcı hastalık değildir. Avrupalıların ayak basmasıyla Amerika, Avustralya ve Pasifik Adaları'nı çok daha kötü salgınlar vurmuştur. 1500'lü yıllarda İspanyolların, Meksika'ya gelmesi ile ortaya çıkan çiçek virüsü salgınını; grip, kızamık ve diğer bulaşıcı hastalıklar izlemiştir (Harari, 2019).

Salgınlar 20. yüzyılda da insanların ölümüne neden olmaya devam etmiştir. 1918'de Amerika'da başlayan ve iki sene boyunca üç dalga halinde yarım milyar insana bulaşan İspanyol gribi, büyük kitlelerin ölümüne yol açmıştır (Temel, 2012). Geçtiğimiz yüzyılda artan dünya nüfusu, gelişmiş ulaşım sistemleri ve küreselleşme yüzünden insanlık, salgınlar karşısında daha da savunmasız hale gelmiştir. Günümüz metropolleri; geçmişe kıyasla patojenler için daha büyük bir yayılma potansiyeli sunmaktadırlar. Kısa periyodlar dahilinde yeni salgın intimalleriyle karşılaşan insanlık, ölüm riskiyle yüzleşmekte ve bu durum gündelik hayatlarını ve yaşam kalitelerini etkilemektedir. 21. yüzyılla birlikte insanlık, yüzyılın ilk pandemisi olan H1N1 /domuz gribi (Yaşar vd., 2011) ile birlikte SARS, MERS, kuş gribi, ve Ebola salgınlarıyla (Zeydan ve Gürbüz, 2020) baş etmiştir. Yeni bulaşıcı hastalıklar çoğunlukla patojenlerin mutasyona uğramasıyla ortaya çıkmaktadır. Bu mutasyonlar sayesinde hayvanlardan insanlara geçen patojenler, aynı şekilde insanların bağışıklık sistemini çökertmekte ve antibiyotik benzeri ilaçlara karşı direnç geliştirmektedir (Harari, 2019).
2019 yılı itibariyleyse insanlık yeni bir salgın hastalıkla karşı karşıya gelmiştir. COVID-19 olarak adlandırılan pandemi, Dünya Sağlık Örgütü'nün tanımlamasına göre, SARS-CoV-2 adı verilen yeni bir koronavirüsün neden olduğu hastalık olup, bu yeni virüs ilk olarak 31 Aralık 2019'da Çin Halk Cumhuriyeti'nin Wuhan kentinde bir dizi "viral pnömoni" vakası raporunun ardından öğrenilmiştir (URL-1, 2020). COVID-19 şu anda küresel olarak tüm ülkeleri etkileyen bir salgındır. Salgın hastalıklarda virüsün sağlıklı kişilere kısa sürede bulaşarak yayılması, akut ve şiddetli seyretmesi, kısa bir süre içinde hastalığa yakalananların hayatlarını kaybetmeleri ya da tamamen sağlıklarına yeniden kavuşmaları, hastalığı geçirmiş ve atlatmış olanların uzun süreli veya hayat boyu bağışıklık geliştirmesi bulaşıCı hastalık sürecinin tipik özelliğidir (Parıldar, 2020). COVID-19 da bulaşıcı hastalıkların tipik özelliklerini gösterdiği için, hastalığın yayılmaya başlamasıyla birlikte "karantina-kişisel karantina" (Self quarantine) ve "izole olmak-izolasyon-kişisel izolasyon" (Self isolation) kavramları gündelik hayatın bir parçası haline gelmiştir. Dünya Sağlık Örgütü'nün tanımlamasına göre karantina, virüse maruz kalınan ve enfekte olunabilen durumlarda, belirlenen bir tesiste veya konutta diğer insanlardan ayrı kalınması anlamına gelmektedir. Karantina, semptomları olsun ya da olmasın, COVID19'a neden olan SARS-CoV-2 virüsü bulaşmış biriyle temas eden herkes için uygulanmaktadır. Izolasyon içinde olmak ise, ideal olarak tıbbi ve klinik bakım alınabilen bir tesiste diğer insanlardan ayrılmak anlamına gelmektedir. İzolasyon, COVID-19 semptomları olan veya virüs için pozitif test yapmış kişiler için uygulanmaktadır. Kişinin tıbbi bir tesiste izolasyon içinde olma imkanı ve kronik bir hastalığı yoksa, izolasyonu konutta gerçekleştirebilmektedir (URL-1, 2020).

COVID-19, küresel anlamda tüm insanların hayatını etkilemiş ve gündelik hayat rutinlerini değiştirmiştir. Yalnızca virüse maruz kalan ve hastalığa yakalanan kişiler değil, tüm dünya kendini olabildiğince koruyabilmek adına, konutlara kapanarak kişisel karantinalarını gerçekleştirmiştir. Çalışma ve eğitim hayatları çevrimiçi ortamlarda devam ettirilmeye çalışılmış, toplumun diğer bireyleriyle, ortak kullanılan alanlarda yapılan faaliyetler kısıtlanmış ve genel olarak konut ortamına taşınmıştır. Bu nedenle konutta geçirilen süre 7/24'e kadar çıkmış, dolayısıyla konutta çalışmanın önemi arttığı için işlevselliği de sorgulanmaya başlanmıştır.

Ayrıca, COVID-19'un, kanser, solunum yolu hastalıkları, diyabet gibi bulaşıcı olmayan kronik rahatsızlıkları olan kişileri daha çok etkilediği ve tehlikeye soktuğu bilgisi ışığında (URL-2, 2020), ülke yönetimlerinin aldığı 
dışarı çıkma yasaklarından en çok etkilenen kesimlerin başında kronik hastalıkları olan bireyler gelmiştir. Türkiye'de Sağlık Bakanlığı ve Bilim Kurulu'nun tavsiyeleri doğrultusunda, il valileri tarafından, İ İdaresi Kanunu'nun 11/C maddesi ve Umuma Hıfzıssıhha Kanun'un 27. ve 72. maddesi kapsamında; 21.03.2020 tarihinden itibaren 65 yaş ve üstü vatandaşlarımızla anılan kronik rahatsızlıklara sahip vatandaşlar ikametlerinden dışarı çıkmaları kısıtlanmıştır (URL-3, 2021). Sağlıklı bireylerin kişisel karantinalarını gerekli olduğu zamanlarda kesip konut mekanı dışında halletmeleri gereken işleri yapabilme imkanı olmuşken, kronik hastalıkları olanların dışarı çıkma şansı uzun bir süre boyunca neredeyse hiç olamamıştır.

Konuta ilişkin söylem; özne, yer, bağlam ve doğa ile fenomenolojik ilişkilerini tartışan eleştirel metinlerle toplumbilim ve felsefede; tekinsizlik kavramının merkezi olarak psikoloji ve edebiyatta; tüm bu kavramların ve retoriklerin uzantısında sanatta tekrar ve tekrar üretilmektedir (Altınyıldız Artun ve Ojalvo, 2018). Konut mekanı, fiziksel boyutunun yanında gündelik aktiviteler ve deneyimleri içeren fiziksel olmayan katmanlardan oluşmaktadır (Lefebvre, 2014). Konut; bürolar, hastaneler, stadyumlar, fabrikalar gibi daha çok evrensel faktörlerle belirlenen fonksiyonların yer aldığı binalardan ziyade, içinde insanoğlunun daha çok özel yaşayışını ilgilendiren konuları kapsamasıyla insanların alışageldiği hayatı daima islah etmek suretiyle yaşayacağı ve mutlu olacağı mekânlardır. Sahip olduğu ya da kiraladığı konutta, kişinin mutlaka alışık bulunduğu, onu saran, cezbeden bir atmosfere ihtiyacı vardır. İşte bu ortamın yaratılmasında bölgesel verilerin, bir başka deyişle çevre ve mevcut hayat şartlarının yerinde değerlendirilmesiyle elde edilecek verilerin rolü büyüktür (Özer, 1987). Yani, evrensel faktörlere göre tasarlanan diğer yapılara göre konutlar, bölgesel verilere göre tasarlanır. Salgın süreci göstermiştir ki, ani gelişen afet, göç, salgın gibi durumlar öngörülemeyen bir takım sonuçları beraberinde getirmektedir. Her birinin kendi özel gereksinimleri olan bu durumlar, kullanıcıların ortaya çıkan koşullara ayak uydurabilecekleri biçimde tasarımlar üretmenin önemini ortaya koymaktadır. İçinde bulunduğumuz süreç, her yaştan, her fiziksel ve zihinsel yeterlilikten insanın birçok yaşamsal eylemi kendi çabalarıyla yerine getirmesi gerekliliğinin her an karşımıza çıkabilecek bir gerçeklik olduğunu hatırlatmıştır. Bu sayede ürün veya mekân tasarımı yapılırken makro çevresel bir yaklaşımla, dışlanmaya izin vermeden tasarım yapmayı amaçlayan "evrensel tasarım" anlayışının ne denli hayati olduğu bir kez daha gözler önüne serilmiştir. Yapılan tasarımın, minimum çabayla kullanıcının ihtiyaçlarını kapsamlı biçimde karşılayabilecek nitelikte olması bir lüks değil, yaşamsal bir ihtiyaç olduğu bir kez daha ortaya çıkmıştır (Arın Ensarioğlu, 2020).

Bununla birlikte, eski hayat düzeninde iç mekan tasarımını mobilya ölçeğine indirgemek, mobilya ile kimliklendirmek, mobilya ile donatmak, bezemek, giydirmek aslında önüne geçilemeyen bir boşluk doldurma motivasyonu ve iç mimarlık mesleğini tanımlar hale gelen bir durum olmuşken, Dünya Sağlık Örgütünün pandemi ilanıyla ve T.C. Sağlık Bakanlığının daha sonra dijital uygulamasına da ismini veren "Hayatı Eve Sığar" mottosuyla birlikte "Yeni Normal" ile tanışılmış ve o andan itibaren, Yeni Normal iç mimarlık disiplininin işlevsel ihtiyaçlardan ödün vermeden, sınırlandırılmış mekanın içinde sınırlandırılmış alt mekanları tasarlamak olduğu görülmüştür. Bu şekilde tasarımın sürecinde doluluk ve boşluk arasında kurulması gereken bağın önemi bu pandeminin varlığıyla gözler önüne serilmiştir (Durukan ve Öztürk, 2020).

Bu bağlamda, araştırmada COVID-19 pandemisiyle önemi daha da artan konut mekanı, fiziksel boyutunun yanında, içerdiği gündelik deneyimlere dair soyut katmanlarıyla ve mobilya ölçeğine indirgemekten çok mekânın, tüm yüzeyleriyle, dolu-boş oranıyla, işlevselliğiyle, mekan organizasyonuyla, mekan büyüklükleri ve bu büyüklüklerin gerçek gereksinimlerle karşılaştırmasıyla, yani kısacası holistik bir bakış açısıyla incelenmesi hedeflenmiştir. Çalışmada konuta ilişkin söylemlere bir bakış açısı daha getirerek, COVID-19 pandemisi sırasında kronik hasta ve sağlıklı bireylerin konut mekanı deneyimlerini ayrı ayrı değerlendirerek bir karşılaştırma yapmak ve varsa gündelik deneyimlere dair farklılıkları ve benzerlikleri saptamak amaçlanmaktadır.

\section{MATERYAL VE YÖNTEM}

Araştırmanın yöntemi olan anket çalışması, dışarı çıkma yasaklarının yoğun şekilde gerçekleştiği dönemde yapıldığı için çalışma alanı Antalya ili içinde sınırlandırılmıştır. Bu nedenle anket örneklem grubu olarak, Antalya Bilim Üniversitesi Güzel Sanatlar ve Mimarlık Fakültesi öğretim elemanları ve öğrencileri seçilmiştir. Anket, konuttaki bireylerden en az birinin hasta olduğu 50 (birinci grup) ve konut mekanını birlikte paylaşan bireylerin tümünün sağlıklı olduğu 50 deneğe (ikinci grup) uygulanmıştır (Tablo 1). Google Forms üzerinden anket çalışması uygulanarak deneklerin konut mekanına dair deneyimleri incelenmiştir. Çalışma kapsamında deneklere 32 soru yönlendirilmiş olup, bu soruların 11'i kısa paragraf sorusu, 21'i çoktan seçmeli soru olmuştur. Denekler, çalışmaya anonim olarak katılmış olup, deneklere istedikleri soruyu boş 
bırakma imkanı tanınmıştır. Ankete katılan deneklerin cevapları, SPSS programında analiz edilmiştir ve değerlendirilerek, yorumlanmıştır.
Örneklem grubu çoğunlukla (\%74) üniversite öğrencileri ve onların konut mekanını paylaştığı kişilerden oluşmakta oluşmaktadır. Yaklaşık \%26'lık bir grup ise öğretim elemanlarını kapsamaktadır (Tablo 2).

Tablo 1. Çalışmanın örneklem grubu

\begin{tabular}{lcccc}
\hline & KADIN & ERKEK & BíLiNMEYEN & TOPLAM \\
\hline Tüm Denekler & 79 & 18 & 3 & 100 \\
Birinci Grup & 41 & 8 & 1 & 50 \\
İinci Grup & 38 & 10 & 2 & 50 \\
\hline
\end{tabular}

Tablo 2. Örneklem grubunun yaş aralıkları

\begin{tabular}{lcccccccc}
\hline & $18-$ & $18-24$ & $25-34$ & $35-44$ & $45-54$ & $55-64$ & $65+$ & TOPLAM \\
\hline Tüm Denekler & - & 74 & 18 & 6 & 1 & 1 & - & 100 \\
Birinci Grup & - & 40 & 8 & 1 & 1 & - & - & 50 \\
İkinci Grup & - & 34 & 10 & 5 & - & 1 & - & 50 \\
\hline
\end{tabular}

100 kişilik örneklem grubunun 50'sinde, deneklerin ya kendisinde ya da konuttaki bireylerden en az birinde hastalık bulunmaktadır. Çalışmada hastalıklar, kronik ve diğer olmak üzere iki grupta toplanmıştır. Kronik hastalıklar içine kanser, $\mathrm{KOAH}$, astım gibi kronik solunum yolu hastalıkları, kalp hastalıkları, epilepsi, böbrek yetmezliği vb. hastalıklar dahil edilmiştir. Diğer hastalıklar grubuna ise yine kronik olan ancak ölüm riskinin daha düşük olduğu diyabet, tansiyon, alerji, kolesterol, hipo/hiper-tiroit, bağırsak rahatsızlıkları, romatizma gibi hastalıklar dahil edilmiştir. Bu bağlamda, kendisinde ya da konuttaki bireylerde hastalık olan deneklerin \%66'sı kronik hastalıklara sahipken; \%34'ü ölüm riski daha az olan "diğer" hastalık grubuna dahildir (Şekil 1). Ayrıca deneklere konuttaki bireylerden zihinsel ve fiziksel engelli olup olmadığı da sorulmuştur. Hiçbirinin konutunda yaşayan kişiler arasında zihinsel engelli birey yokken; 2 tanesinin konutunda fiziksel engelli birey bulunmaktadır.

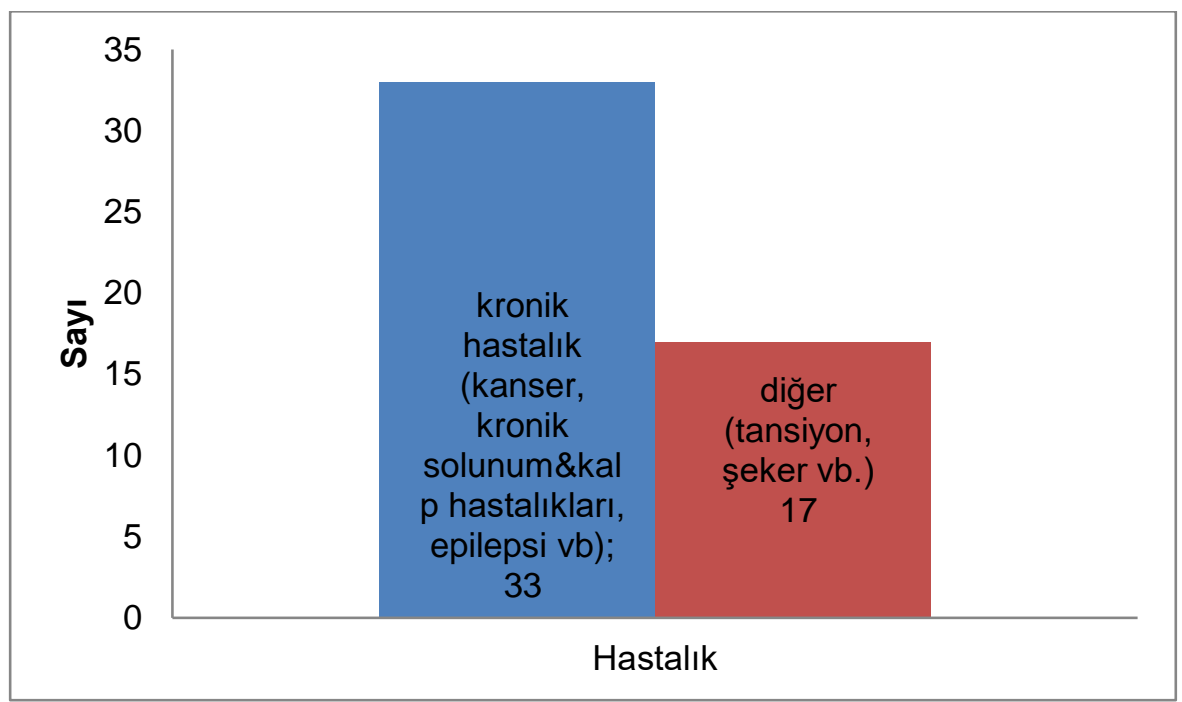

Şekil 1. Birinci grupta konutta yer alan hasta bireylerin hastalık türleri

\section{BULGULAR}

Deneklerden yaşamakta oldukları konutta, pandemi dönemi göz önünde bulundurulduğunda konutlarında karşılaştıkları mekânsal ilk üç problemi, önem sırasıyla, en önemlisi başa gelecek şekilde sıralamaları istenmiştir. Elde edilen cevaplar "renkle kodlama" tekniği kullanılarak kategori/parametre haline getirilmiş ve en çok ortaya konmuş olan problemler belirlenmiştir. Her bir deneğin 
bu soruya birden çok yanıt verdiği göz önünde bulundurulduğunda, çıkan parametrelerin toplamının denek sayısından çok olması kaçınılmaz olmuştur. Burada tüm bireylerin sağlıklı olduğu konutlardaki pandemi sürecine dair kullanıcı deneyimini, konutta en az bir hasta bireyin olduğu konutlardaki deneyimle karşılaştırmak ve süreç üzerinde iki grubun farklı ve benzer deneyimlerini ortaya koymak amaçlanmıştır. Bu soru açık uçlu olarak deneklere yöneltilmiş olup, soruya kısa paragraf şeklinde yanıt vermeleri istenmiştir. Ankette bu soru haricinde, deneklerin konut koşullarını anlayabilmek adına sorular sorulmuştur. Eğer ankette, bu belirlenen parametrelerden birine dair bir soru varsa, o parametre o sorunun verileriyle birlikte değerlendirilerek analiz edilmiştir.
Birinci ve ikinci gruptaki deneklerin verdiği cevaplar, renkle kodlama tekniğiyle benzer cevapların bir araya getirilmesiyle kategorileştirilmiş ve parametreler oluşturulmuştur. Parametreler, tüm deneklerin cevapları incelenerek belirlenmiş olup, gruplardan birinde bir parametreden bahsedilmemişse sıfır olarak tanımlanmıştır. Burada, iki grubun cevaplarını aynı parametreler bağlamında değerlendirerek, benzer ve farklı yönlerin ortaya konmasını kolaylaştırmak amaçlanmıştır (Şekil 2-3).

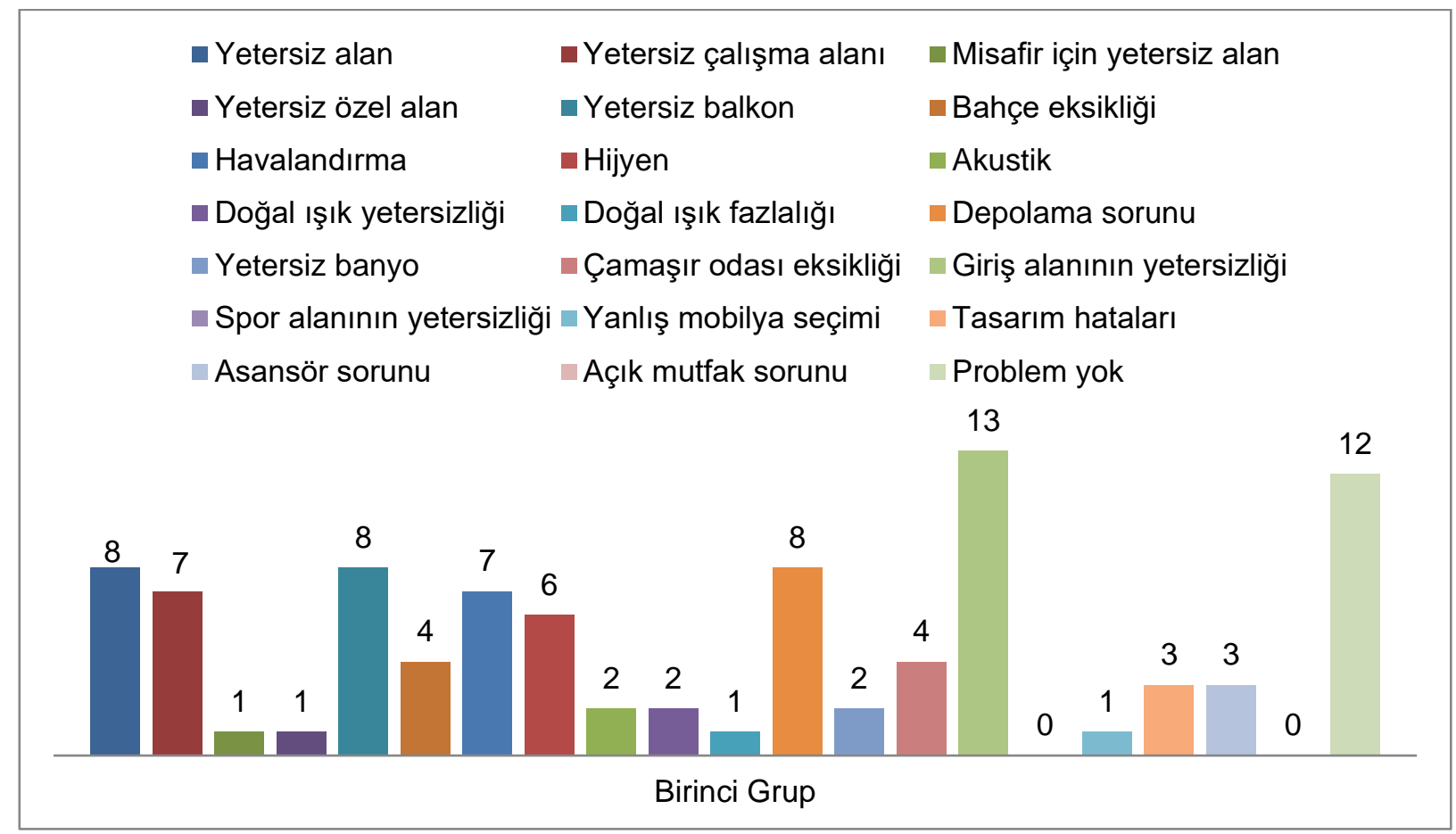

Şekil 2. Konuttaki mekânsal ilk üç sorun (birinci grup) 


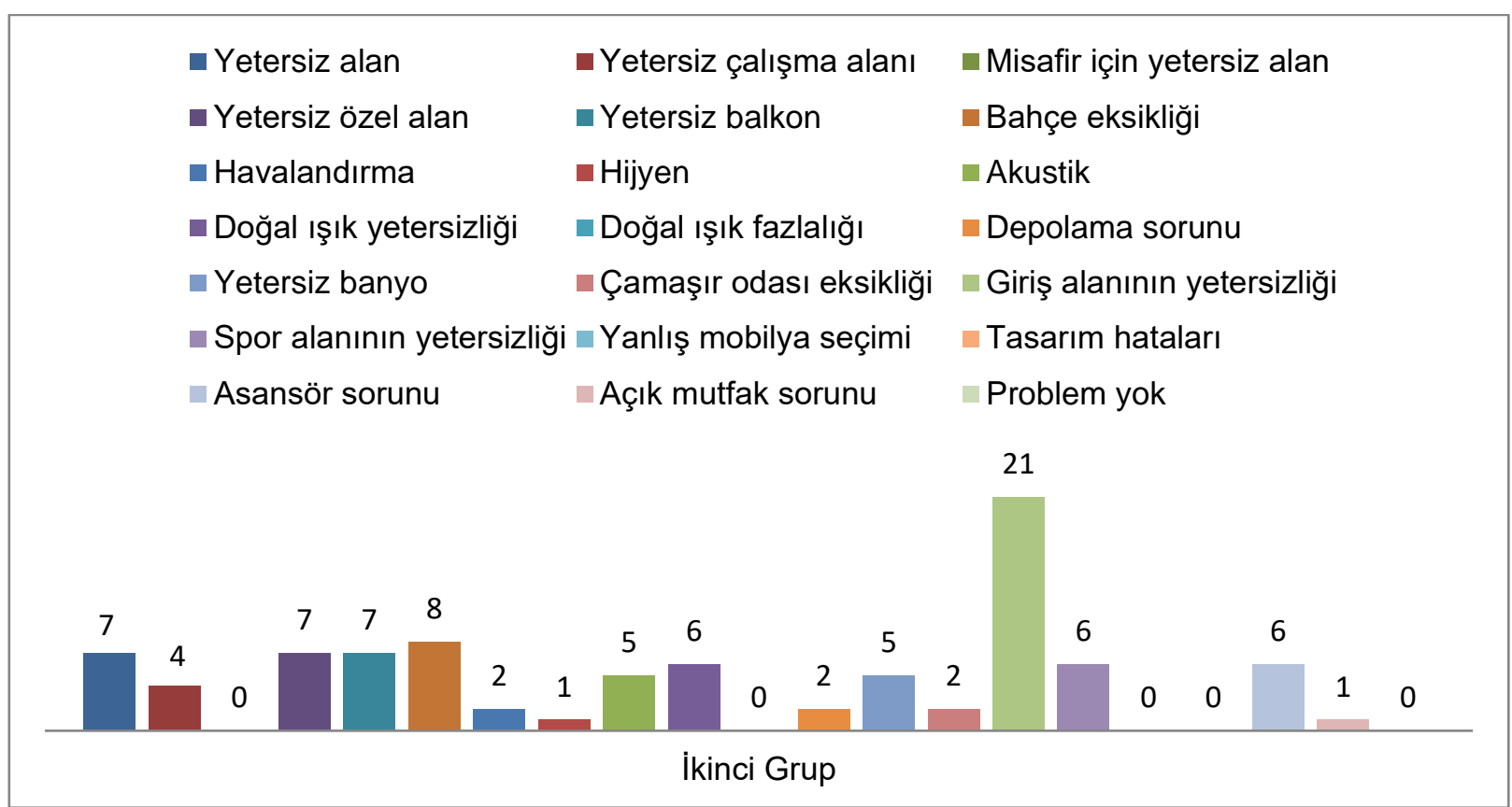

Şekil 3. Mekânsal ilk üç sorun (ikinci grup)

Bu bağlamda, iki grupta da öne çıkan cevaplardan biri "yetersiz alan" olmaktadır. Konutta kalma sürelerinin pandemi nedeniyle çok uzamasıyla birlikte deneklerin konutlarında karşılaştıkları en önemli mekânsal problemlerden biri olarak "yetersiz alan" çıkması kaçınılmazdır. Birinci grupta bu parametreyi dile getiren 8, ikinci grupta 7 kişi bulunmaktadır. Bu parametreyle birlikte deneklerin konut mekânını paylaştığı kişi sayısı ve konuttaki oda sayısı verileri incelenmiştir. Birinci gruptaki deneklerin yalnızca \%2'sinin yalnız yaşadığı ve çoğunluğunun konutlarında 3 ya da 4 kişi barındığı görünmekteyken; ikinci grupta yalnız yaşayan sayısı çok daha fazladır. İkinci grup da konutlarında yüksek oranda 3 ya da
4 olarak yaşamaktadır (Tablo 3). Oda sayısı olarak bakıldığında ise, birinci ve ikinci grupta en çok $3+1$ büyüklüğünde konutlarda ikamet edildiği görülmekte ve onu sırasıyla $4+1$ ve $2+1$ konutlar takip etmektedir (Tablo 4). Bu veriler incelendiğinde, her ne kadar deneklerin genelinde konutu paylaşan her bireye birer oda düşen konut mekân düzenleri görülse bile, 5 veya daha üstü kişinin bir arada yaşadığı konutlardaki denekler arasında $3+1$ ve 4+1 konutlarda yaşayanlar da mevcuttur. Bu düzende denekler arasında özel alanlarını konutun başka üyeleriyle de paylaşma zorunlulukları doğması, kişilerin kişisel karantina, iş ve okul için sessiz mekân ve kişisel mahremiyeti sağlamakta zorlanmalarına neden olabilecektir.

Tablo 3. Örneklem grubunun konut mekânını paylaştığı kişi sayısı

\begin{tabular}{lccccccc}
\hline & $\begin{array}{c}1 \text { (yal- } \\
\text { nIz) }\end{array}$ & 2 & 3 & 4 & 5 & $\begin{array}{c}6 \text { ve } \\
\text { üstü }\end{array}$ & TOPLAM \\
\hline Tüm Denekler & 7 & 7 & 32 & 42 & 10 & 2 & 100 \\
Birinci Grup & 1 & 4 & 16 & 22 & 5 & 2 & 50 \\
İinci Grup & 6 & 3 & 16 & 20 & 5 & - & 50 \\
\hline
\end{tabular}


Tablo 4. Örneklem grubunun konut mekânını paylaştığı kişi ve konutlarındaki oda sayısı

\begin{tabular}{|c|c|c|c|c|c|c|c|c|c|}
\hline & $1+1$ & $2+1$ & $3+1$ & $4+1$ & $5+1$ & $6+1$ & $6+2$ & Bilinmeyen & TOPLAM \\
\hline $\begin{array}{l}1 \text { (yalnız yaşa- } \\
\text { yanlar) }\end{array}$ & 2 & 4 & 2 & - & 1 & - & - & - & 9 \\
\hline 2 & - & - & 5 & 1 & 1 & - & - & - & 7 \\
\hline 3 & - & 4 & 23 & 5 & - & - & - & - & 32 \\
\hline 4 & - & 4 & 21 & 8 & 6 & - & 1 & - & 40 \\
\hline 5 & - & - & 6 & 2 & 1 & 1 & - & - & 10 \\
\hline 6 ve üstü & - & - & - & - & - & - & - & 2 & 2 \\
\hline TOPLAM & 2 & 12 & 57 & 16 & 9 & 1 & 1 & 2 & 100 \\
\hline
\end{tabular}

Ayrıca, veriler doğrultusunda ortaya çıkan diğer bir parametre olan "yetersiz özel alan" ise, birinci grupta 1 , ikinci grupta 7 denek tarafından ortaya konmuş olup, bu bilgileri desteklemektedir. Bu parametreyi ankette sorulan "konutunuzda kişisel mahremiyetinizi sağlayacak alan var mı?" sorusunun verileriyle incelemek gerekmektedir. Buna göre, birinci gruptakilerin \%82'si ve ikinci gruptakilerin \%78'i konutlarında kişisel mahremiyetlerini sağlayacakları alanlarının bulunduklarını belirtmiştir. Bi- rinci gruptan 9, ikinci gruptan 11 kişi kişisel mahremiyetlerini sağlayamadıklarını belirtmiştir. Bu soruya olumsuz yanıt verenlerin konutlarının oda sayısı ve konutta yaşayan kişi sayısı verileriyle birlikte SPSS üzerinden analizleri gerçekleştiğinde ise, genellikle $2+1$ ve $3+1$ konutlarda yaşayan (Şekil 4) ve konut mekânını 3 veya 4 kişinin paylaştı̆̆ (Şekil 5) deneklerin kişisel mahremiyetlerini korumakta zorlandıkları ortaya konmuştur.

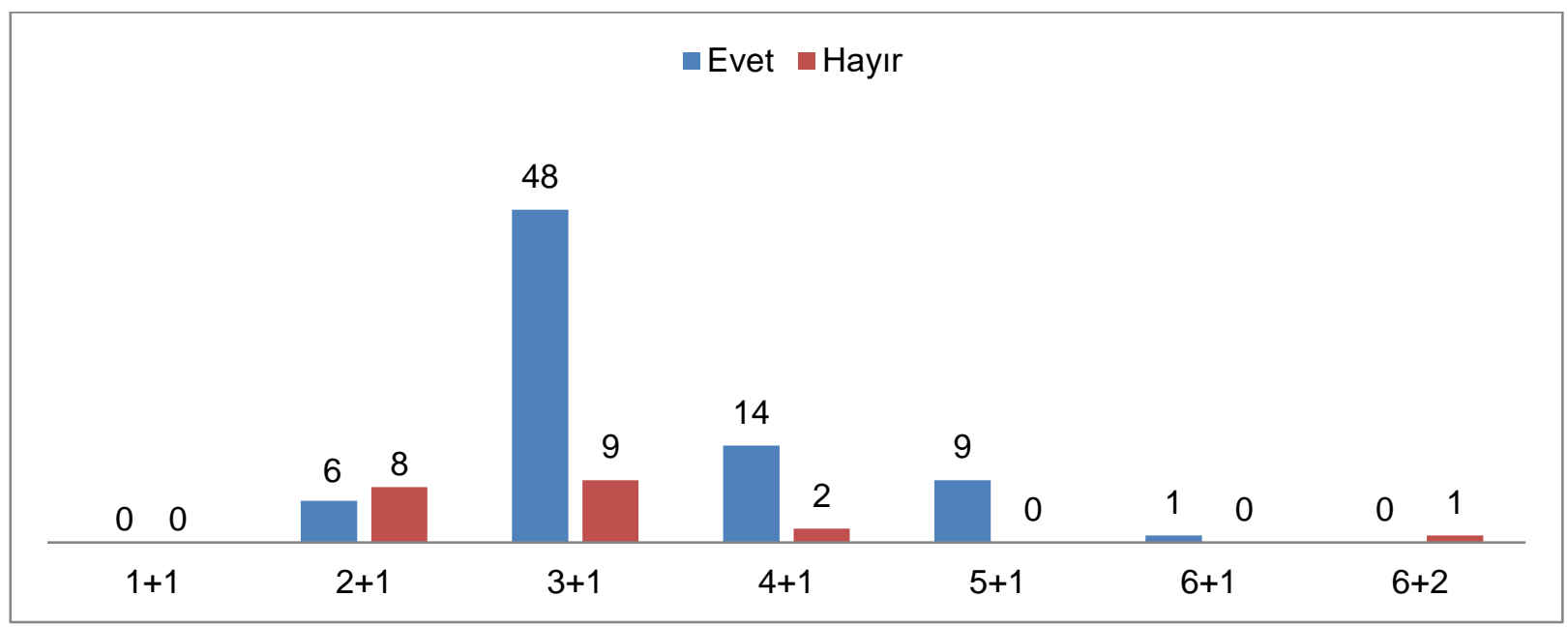

Şekil 4. Kişisel mahremiyet- konuttaki oda sayısı ilişkisi 


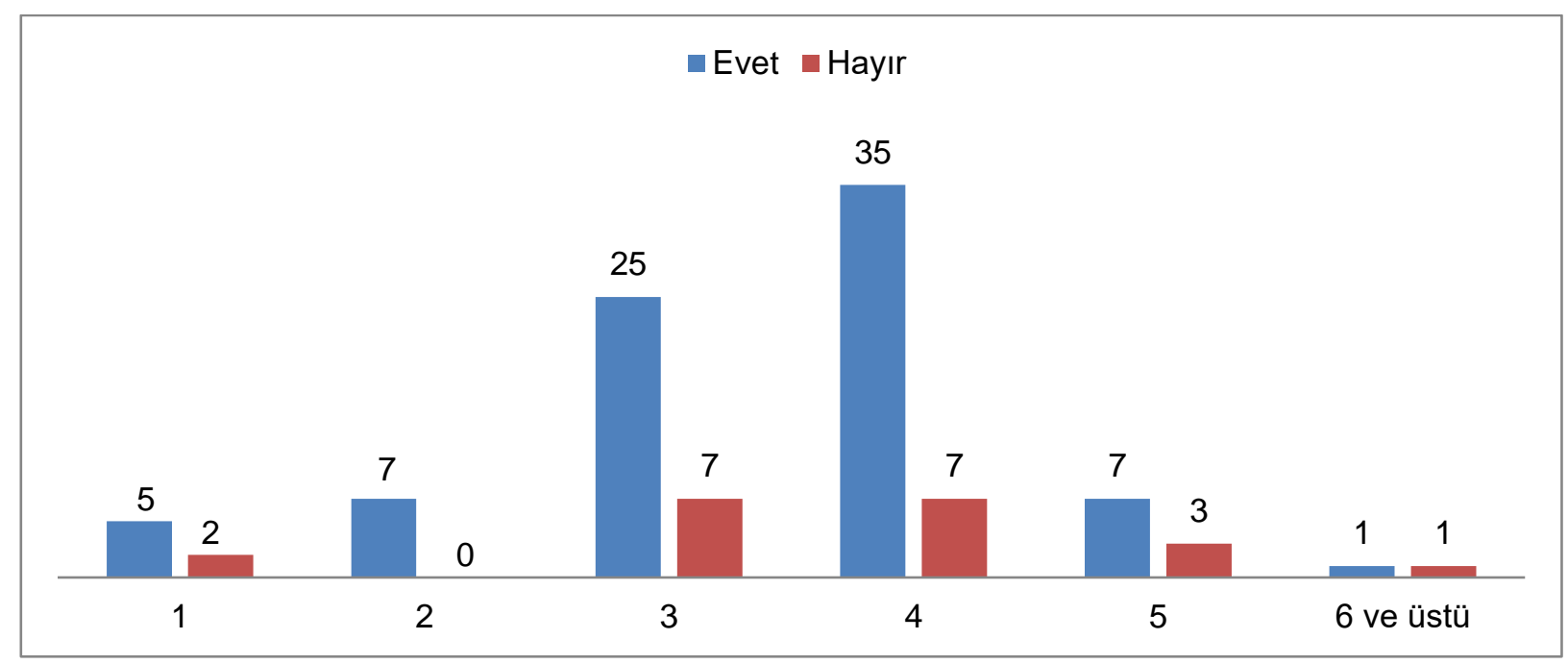

Şekil 5. Kişisel mahremiyet - konuttaki kişi sayısı ilişkisi

Bu parametrelerle paralellik gösteren diğer parametreler ise "yetersiz çalışma alanı" ve "akustik problemler" olarak saptanmıştır. Birinci grupta yetersiz çalışma alanını mekânsal sorun olarak belirten 7 denek varken, ikinci grupta 4 kişi vardır. Akustik problemleri ise birinci grupta 2, ikinci grupta 5 kişi önemli bir mekânsal problem olarak belirtmiştir. Akustik problemler için deneklere konut mekanlarının sessiz mekan intiyaçlarını karşılayıp karşılamadıkları sorulmuştur. Birinci gruptaki deneklerin \%76'sı, ikinci gruptakilerin \%68'i konutlarının sessiz mekân intiyaçlarını karşıladıklarını belirtmiştir. Her ne kadar çoğunluğun sessiz mekân konusunda sorun yaşamadığı görünse de, tüm deneklerin yaklaşık \%30'unun konut içinde sessiz mekâna sahip olmakta sorun yaşadıkları ortaya çıkmaktadır. Bu durum yetersiz alan/yetersiz özel alan sorunlarından kaynaklanabilmektedir. Odaları konuttaki diğer bireylerle ortak kullanmak zorunda kalmak, aynı anda iki kişinin de oda içerisinde çevrimiçi derse bağlanmak zorunda kalması ya da toplantı yapması gibi durumlardan kaynaklı olabilir. Ancak çalışmadaki veriler, bu konuda dış etkenlerin de önemli olabileceğini ortaya koymaktadır. Çünkü SPSS üzerinden yapılan analizlerde, sessiz mekânla ilgili soruya "evet" ya da "hayır" diyenlerin hangi büyüklükteki konutlarda ve kaç kişi olarak yaşadıkları bilgileriyle karşılaştııılarak da incelenmiştir. Buna göre $6+2$ bir konutta yaşamını sürdüren bir bireyin de sessiz mekâna erişmekte zorlandığı görülmektedir (Şekil 6). Kişi sayısına göre bakıldığında ise, yalnız yaşayan bireyler arasında da sessiz mekân sorunu yaşadıkları ortaya çıkmaktadır (Şekil 7). Sessiz mekânla ilgili en çok sorun yaşayan denekler $2+1$ ve $3+1$ konutlarda, hane halkının 3 veya 4 kişiden oluştuğu denekler olmuştur. Bu analizler sessiz mekana dair sorunların yalnızca konuttaki bireylerden kaynaklanmadığı, yakın çevre ve komşular gibi nedenlerle de sorunların oluşabileceği sonucunu vermektedir.

Yapılarda işitsel konfor, kişilerin işlerindeki verimi büyük ölçüde etkilemektedir. Özellikle gürültülü yerlerde inşa edilmiş ve gerekli yalıtım yapılmamış konutlarda, uykusuzluk problemine neden olan gürültü, ortamdaki kişinin mutsuz, verimsiz, fiziki ve psikolojik açıdan sağlıksız olmasına neden olur (Gürel ve Ülkü, 2007). Bu nedenle konutlardaki sessiz mekân sorunu yeni normalde mutlaka dikkate alınması gereken konuların başında yer almaktadır. 


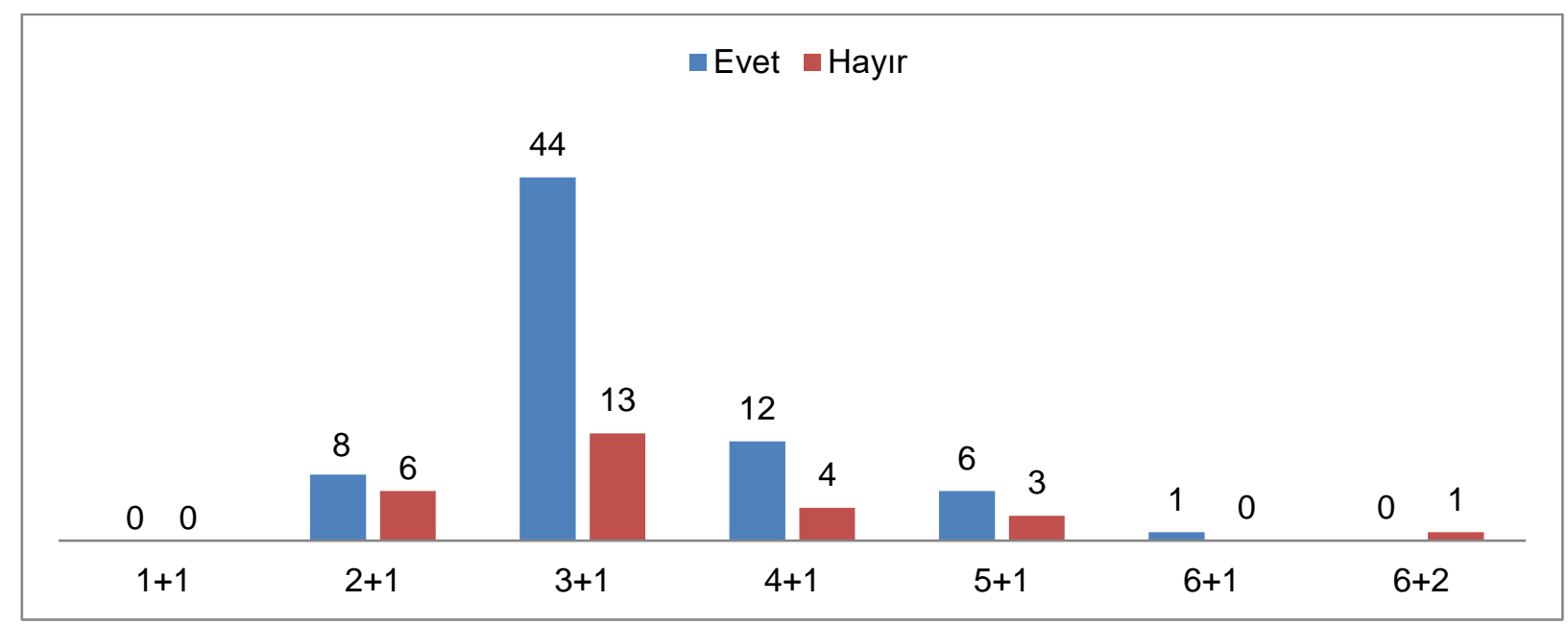

Şekil 6. Sessiz mekân- oda sayısı ilişkisi

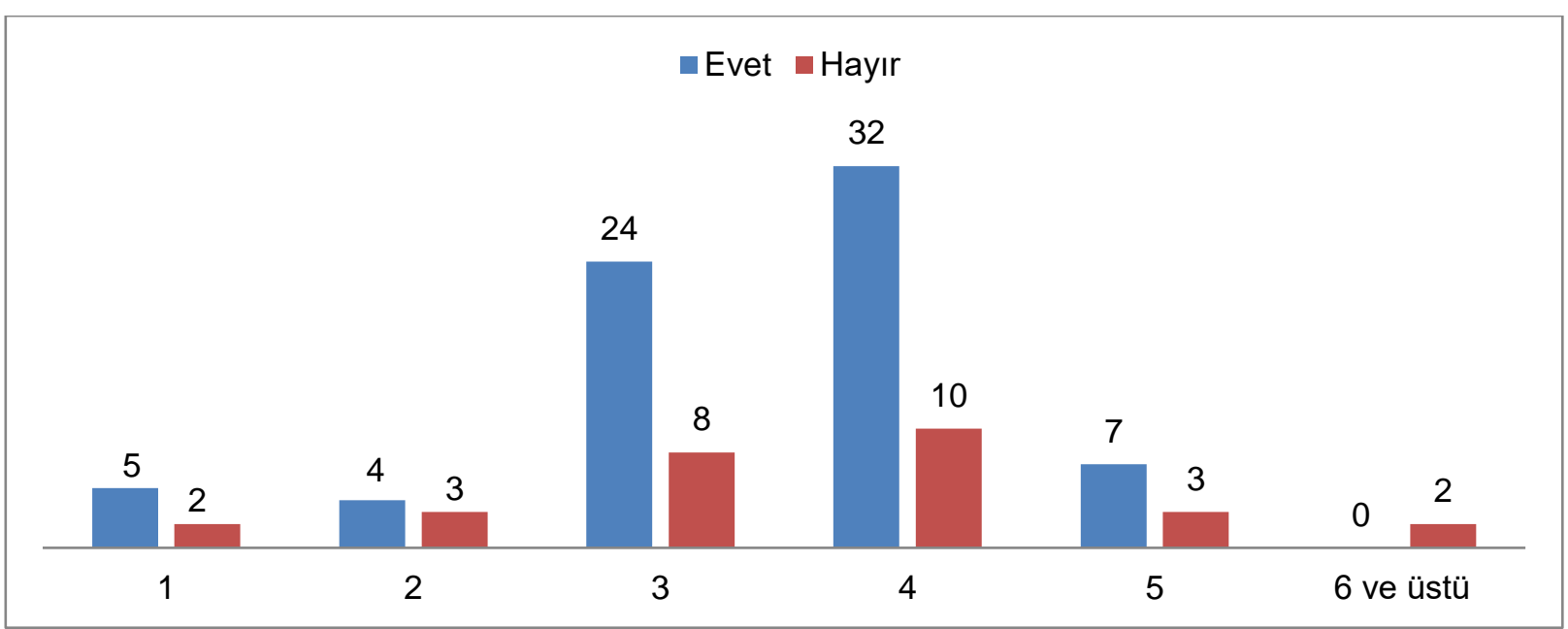

Şekil 7. Sessiz mekân- konuttaki kişi sayısı ilişkisi

"Misafir için yetersiz alan" ve "spor alanının yetersizliği" de diğer parametrelerdendir. Deneklere pandemi sürecinde konutlarını barınma haricinde başka hangi amaçlarla kullandıkları sorusu yöneltilmiş ve denekler, konutlarını "iş" ve "üniversite eğitimi" haricinde en çok spor yapma ve sosyalleşme amacıyla kullandıklarını belirtmiştir. Bu parametrede, konutunda en az bir hasta birey olan denekler arasında "spor alanının yetersizliği" sorunundan bahseden kimse bulunmazken, konutu paylaşan herkesin sağlıklı olduğu ikinci gruptaki deneklerden 6 tanesi bu sorunu dile getirmiştir. Bu durum bu parametreyi, çalışmadaki iki grup arasındaki önemli farklardan biri yapmaktadır. Misafir için yetersiz alan parametresi ise birinci grupta 1 kişi tarafından sorun olarak belirtilirken, ikinci gruptakiler arasında bu sorundan bahseden olmamıştır.
"Giriş alanının yetersizliği" öne çıkan diğer bir parametredir. Birinci gruptan 13, ikinci gruptan 21 denek bu sorunu dile getirmiştir. Bu parametre, öncelikle deneklere konutlarında antre/giriş mekanının olup olmadığı yönündeki sorunun verileriyle analiz edilmek istenmektedir. Buna göre, birinci gruptakilerin \%92'si ve ikinci gruptakilerin \%86'sının konutunda giriş mekânı bulunmaktadır. Deneklere ayrıca konutlarının giriş mekânına ayakkabıyla girip girmedikleri ve girişle diğer mekânlar arasında bir kot farkı olup olmadığı da sorulmuştur. Yalnızca birinci gruptakilerin \%10'unda giriş ve diğer mekanlar arasında kot farkı olduğu sonucu ortaya çıkmıştır. Hijyen açısından önem taşıyan bu kot farkı durumunun, konutta hasta bireylerin bulunduğu denekler tarafından daha çok dikkat edilmiş olduğu anlaşılmaktadır (Şekil 8). Konuya dair diğer bir soru ise ayakkabı dolabının bulunduğu yerdir. Bu soruda da bir öncekinde olduğu gibi konutunda hasta birey bulunan birinci grup denekler tarafından daha çok dikkat edilen bir parametre olarak görülmekte 
olup, birinci gruptakilerin \%18'inin, ikinci gruptakilerin ise \%6'sının ayakkabı dolabının konut mekânının dışında konumlandığı anlaşılmaktadır (Şekil 9). Konutların giriş mekânlarının genellikle kapısız olması ve konutların ya koridorlarıyla ya da salon-mutfak gibi diğer mekânlarıyla kapısız şekilde birleşmesi göz önünde bulundurularak deneklere giriş mekânının koridor vd. mekânlardan kapıyla ayrılmasını tercih edip etmedikleri sorulmuş olup, iki grupta da yüksek oranda olumlu cevapla karşılaşılmıştır (Şekil 10).

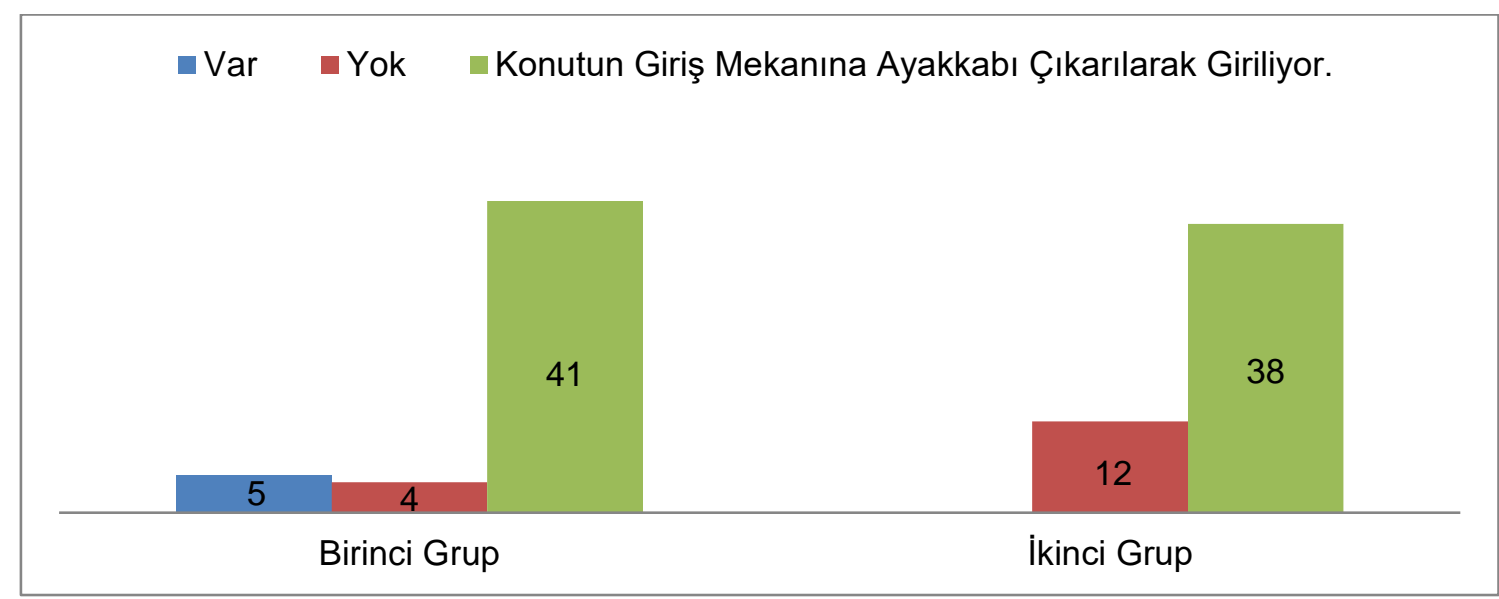

Şekil 8. Konutun giriş mekânına ayakkabıyla giriliyorsa, bu alan ile konuttaki diğer mekânlar arasında kot farkı varIığı

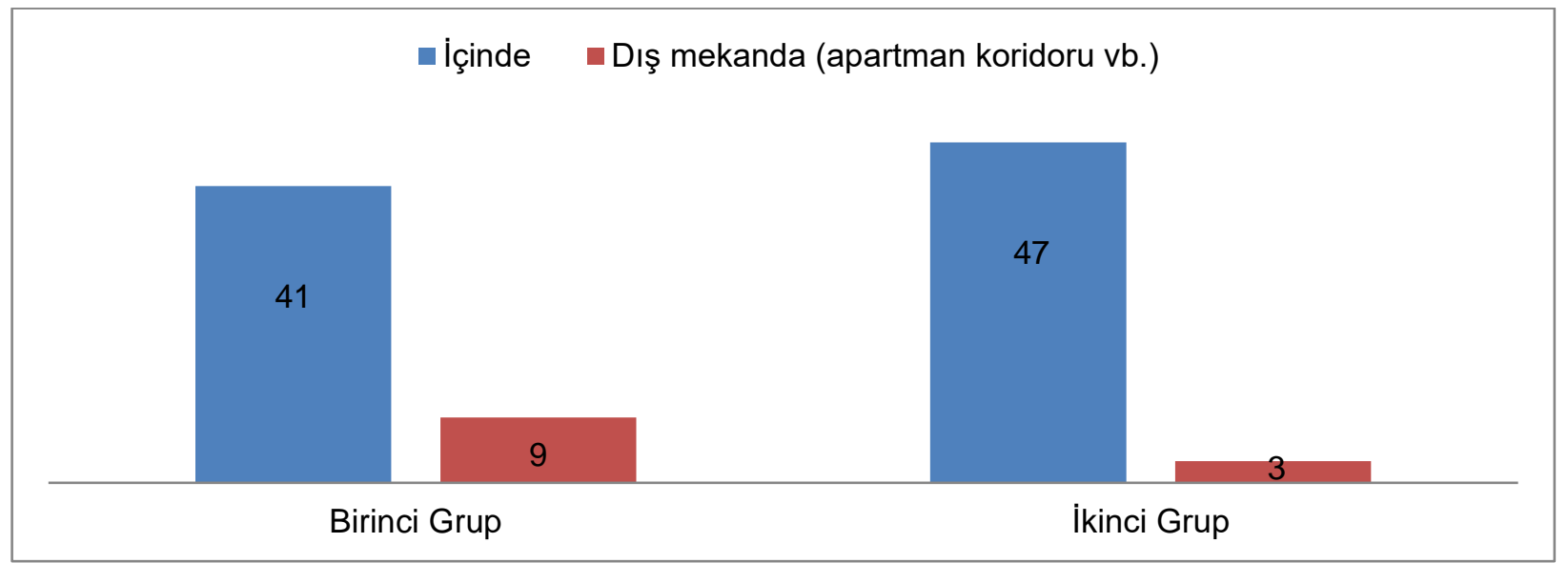

Şekil 9. Ayakkabı dolabının konuttaki konumu

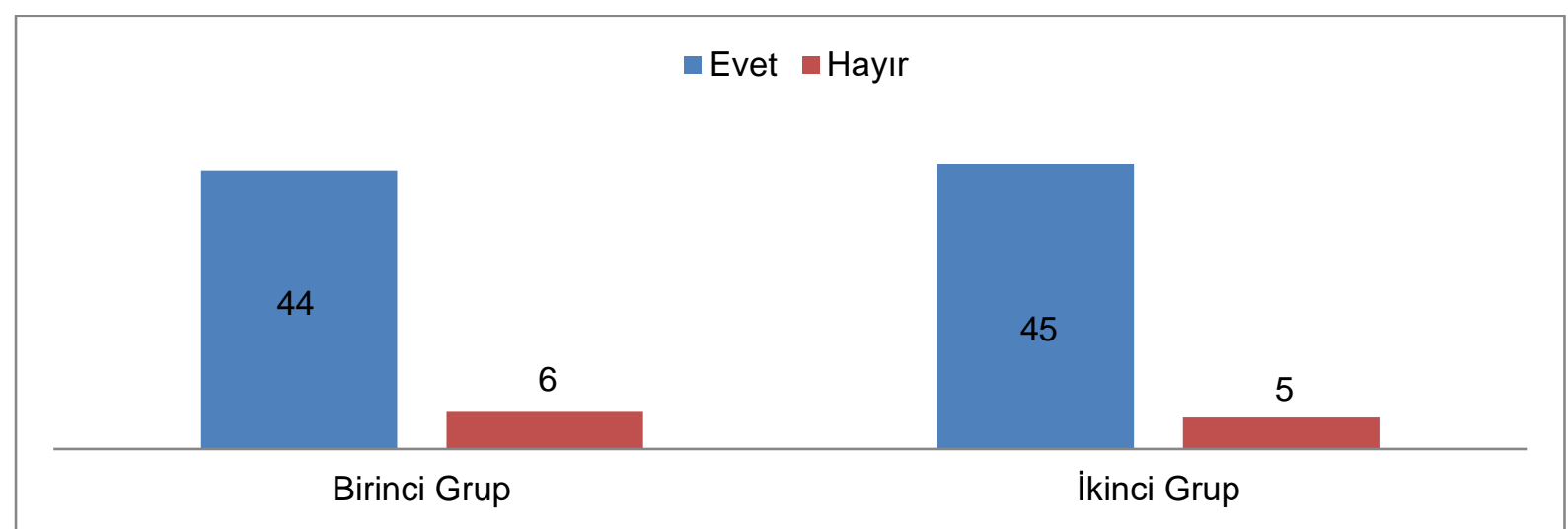

Şekil 10. Konutun giriş mekânının konutun koridoru vb. bir alana bağlanmadan önce, ikinci bir giriş kapısıyla ayrılması isteği 
Aslında genel anlamda "hijyen" parametresiyle de önemli bir ilişki içinde olan bu parametreler, giriş mekânının önemini bir kere daha ortaya koymaktadır. Birinci grup deneklerin \%12'si ve ikinci gruptakilerin \%2'si hijyen sorununu önemli bir mekânsal sorun olarak belirtmiştir. Daha önceki parametrelerde, birinci ve ikinci gruptaki deneklerin cevapları paralellik gösterse de, hijyen konusu devreye girdiğinde konutunda en az bir hasta bireyin bulunduğu denekler ve tüm bireylerin sağlıklı olduğu denekler arasındaki cevapların oranlarında farklılıklar oluşmuştur. Bu parametre, deneklerin diğer bir önemli mekânsal sorun olarak belirttiği "yetersiz banyo" ile ortak özelliklere sahip olduğu düşünülerek, konutlardaki genel banyo, genel WC ve odalara bağlı
banyo/WC verileri göz önünde bulundurularak analiz edilmek istenmektedir. Öncelikle birinci gruptakilerin $\% 4$ 'ü ve ikinci gruptakilerin \%10'u yetersiz banyo alanı nedeniyle sorun yaşadıklarını belirtmiştir. Deneklerin konutlarındaki genel banyo sayıları incelendiğinde, iki grupta da $\% 80$ ve üstü bir oranda 1 adet genel banyo olduğu görülmektedir (Şekil 11). Genel WC sayılarına bakıldığında ise, birinci gruptakilerin, ikinci gruptakilerden \%10 oranında daha çok genel WC'ye sahip oldukları belirtilmiştir (Şekil 12). Birinci ve ikinci gruptaki denekler arasında odalara ait banyo/WC olan konutlarda barınanların oranı ikinci grupta daha fazladır (Şekil 13).

$$
\square 1 \square 2 \square 3 \square 0
$$

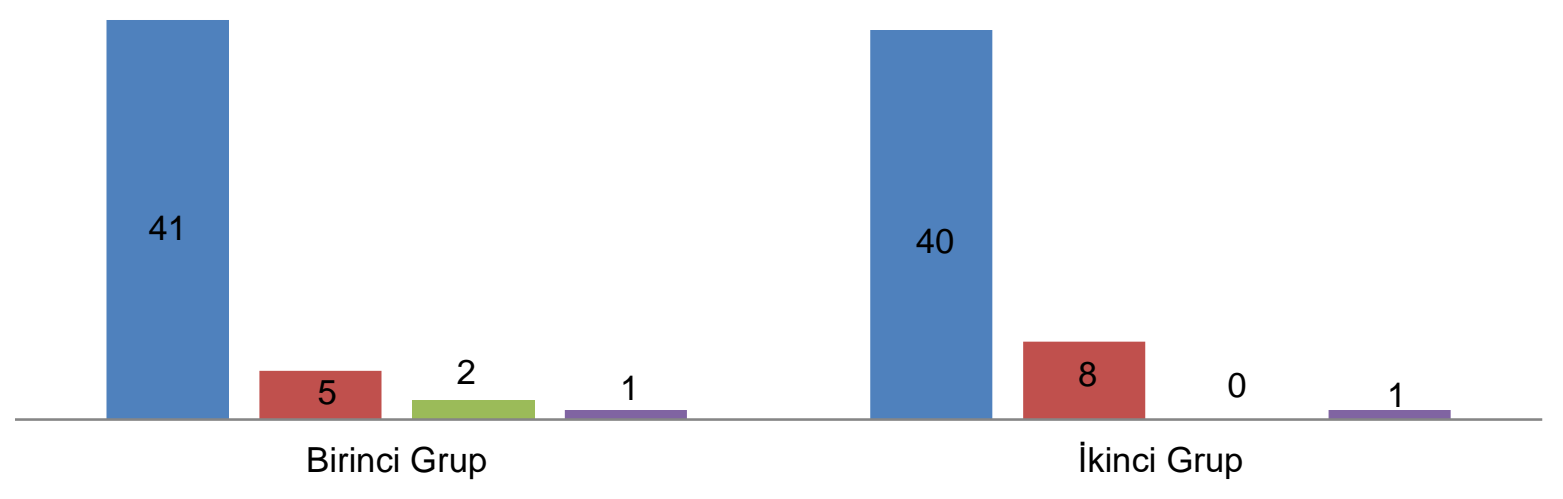

Şekil 11. Konuttaki genel banyo sayısı

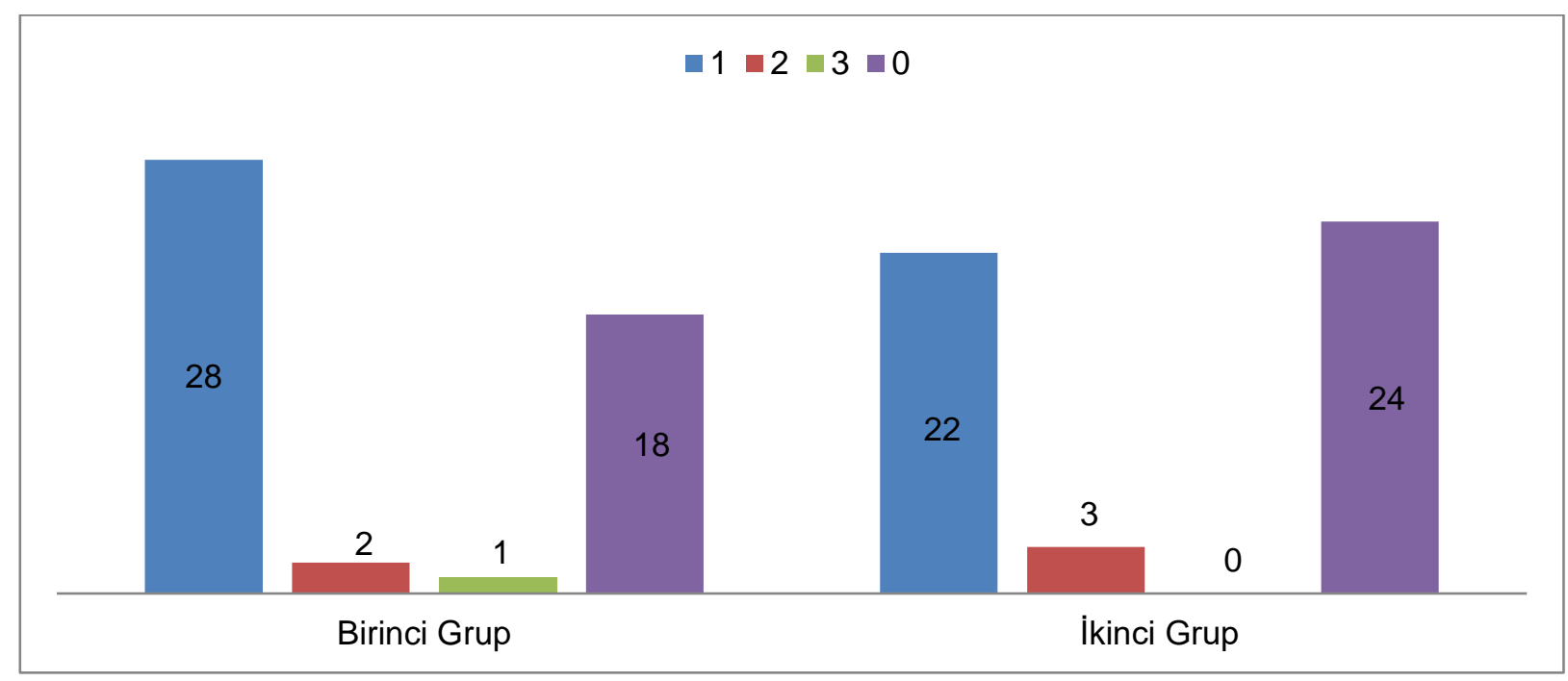

Şekil 12. Konuttaki genel WC sayısı 


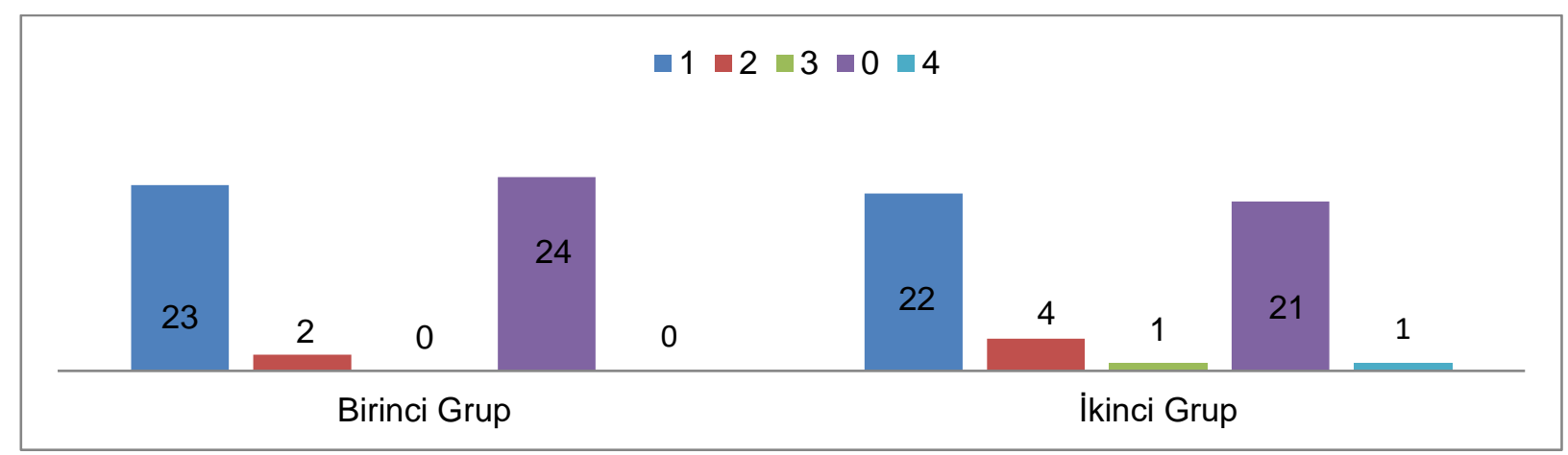

Şekil 13. Odalara bağlı banyo sayısı

Pandemiyle birlikte konutlarda önemli hale gelen konuların başında, dışarıdan konuta gelindiğinde kıyafetlerin izole bir ortamda çıkarılması, üzerlerinde virüs varsa konutun geri kalan kısmına yayılmaması ve dışarıdan getirilen paketlerin belirli bir süre bir yerde bekletilerek üstünde virüs varsa etkisiz hale gelmesi beklentisi gelmektedir. Bu nedenle giriş mekânlarından sonra, konutlarda çamaşır odalarının olup olmaması, konumu ve alışveriş, kargo vb. paketler için depolama alanlarının büyüklükleri konutlardaki mekânsal sorunların başını çekmektedir. Denekler de bu doğrultuda "çamaşır odası eksikliği" ve "depolama sorunları" parametrelerini belirtmiştir. Buna göre çamaşır odası eksikliği birinci grupta \%8, ikinci grupta $\% 4$ oranında; depolama sorunları ise birinci grupta \%16, ikinci grupta \%4 oranında belirtilmiştir.

Konut mekânında en az bir hasta bireyin yaşadığı birinci grup için depolama sorununun daha önemli olduğu anlaşılmaktadır. Hem kronik hasta olanların devletin belirlemiş olduğu dışarı çıkma yasaklarından daha çok etkilenmeleri hem de zaten kronik hasta olmaları nedeniyle sağlıklarının daha çok tehlike altında olması nedeniyle, alışverişlerini toplu olarak gerçekleştirmelerinin gerekmesi, depolama sorununu daha çok yaşamalarına neden olabilmektedir. Bu iki parametre deneklere anket içerisinde farklı sorularla sorulmuştur. Birinci grupta yalnızca \%18'ık bir oranda deneğin konutunda çamaşır odası varken, bu kişilerin yalnızca \%4'ünün konutundaki çamaşır odası girişe yakın konumdadır. İkinci grupta \%32'sinin konutunda çamaşır için ayrı bir odası bulunmakta olup, bunların \%16'sı konutlarındaki çamaşır odalarının girişe yakın olduğunu belirtmiştir. Konutlarındaki depolama alanını ise; birinci grubun \%80'i, ikinci grubun $\% 84$ 'ü yeterli bulmuştur. Birinci grupta konutlarındaki depolama alanını yeterli bulmayan 10 denek vardır. Bunların 8 tanesi, bu sorunu konutlarındaki en önemli üç sorundan biri olarak dile getirmiştir. Bu da, pandemi sürecinde hasta bireylerin olduğu konutlarda depolama alanının ne kadar önemli olduğunu bir kez daha ortaya koymaktadır.

Deneklerin dile getirdiği diğer bir sorun ise açık mutfak sorunudur. Birinci gruptan bu sorunu dile getiren kimse yokken, ikinci gruptan bir denek (\%2) bu sorundan bahsetmiştir. Bu nedenle "açık mutfak sorunu" parametresi de açık mutfak konusunda deneklere yöneltilmiş sorunun yanıtlarıyla birlikte analiz edilecektir. Deneklerden konutlarındaki mutfak tiplerinin belirtilmesi istendiğinde, birinci gruptakilerin \%24'nün Amerikan mutfak olarak da adlandırılan salonla, \%2'sinin ise girişle birleşik mutfaklarının olduğu görülürken; ikinci gruptakilerin de buna oldukça yakın cevaplar verdiği anlaşılmaktadır (Şekil 14). Açık plan çözümleri, konut mekânını paylaşan kişi sayısı arttıkça sosyal mesafe ve kişisel karantina gibi koşulları sağlamakta zorluk yaratmaktadır. 


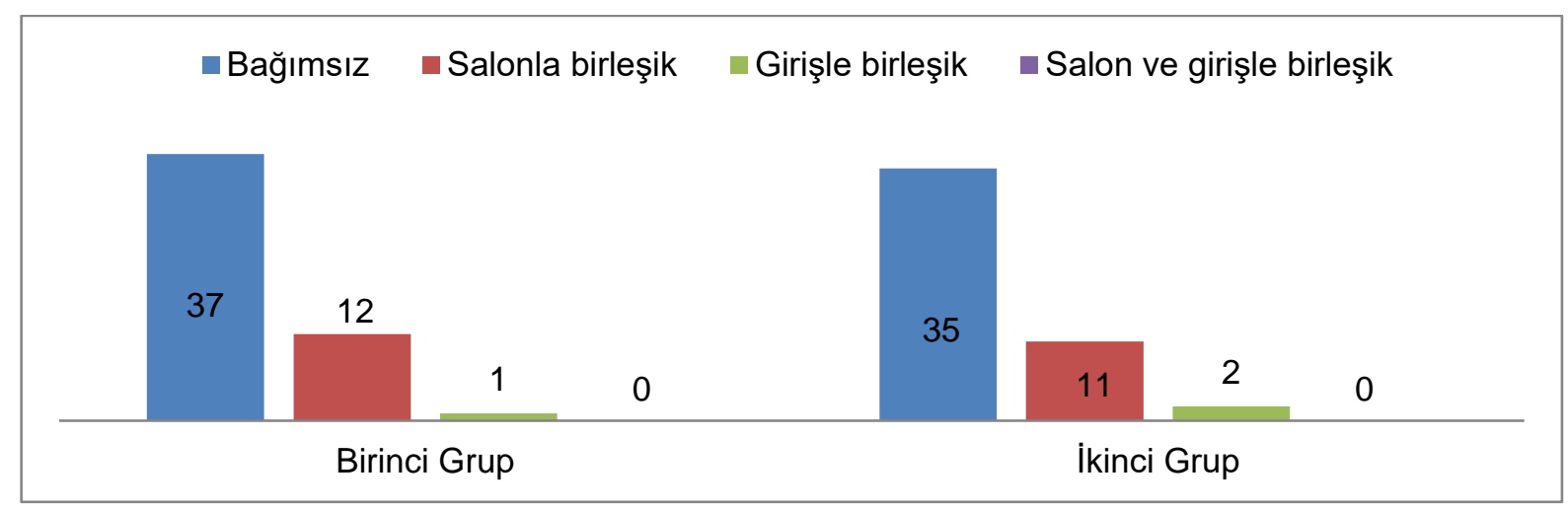

Şekil 14. Konuttaki mutfak tipleri

Şimdiye kadar gözden geçirilen parametrelerin tamamı, konutta yaşayan bireylerden birinin, pandemiye yakalanması nedeniyle kişisel karantina gerçekleştirmesi gibi bir durum söz konusu olduğunda on dört gün boyunca konuttaki diğer bireylerden soyutlanarak barınma ve diğer intiyaçlarını giderip gideremeyeceğini anlamak adına önemlidir. Ancak yine de deneklere direkt olarak pandemi nedeniyle kişisel karantinaya girmeleri gerektiğinde konutlarının buna elverişli olup olmadığı sorulmuştur. Birinci gruptakilerin \%30'u, ikinci gruptakilerin \%28'i konutlarının bunun için uygun olmadığını dile getirmiştir. $\mathrm{Bu}$ da, hane içindeki bireylerden birinin hastalığa yakalanması durumunda, konuttaki diğer bireylere bulaştırma intimalinin bulunduğunu göstermektedir.

Denekler "bahçe eksikliği"ni ve "yetersiz balkon"u konutlarındaki önemli mekânsal sorunlar olarak belirtmiştir. Bu bağlamda birinci grupta $\% 8$ ve ikinci grupta $\% 16$ oranında bahçe eksikliği parametresi dile getirirken, yetersiz balkon sorununu birinci gruptakilerin $\% 16$ 'sı ve ikinci gruptakilerin \%14'ü dile getirmiştir. Bu parametreler, konutlardaki mavi-yeşil mekânlar olan balkon, teras ve veranda hakkında deneklere yöneltilmiş soruların yanıtlarıyla birlikte analiz edilmiştir. Birinci gruptakilerin \%86'sında, ikinci gruptakilerin \%78'inin konut mekânlarında teras veya veranda bulunmamaktadır. Deneklerin tamamının konutunda küçük de olsa bir balkon bulunmaktadır. Ancak, birinci gruptakilerin \%8'inin ve ikinci gruptakilerin \%6'sının balkonu kapatılmış ve iç mekana dahil edilmiş bulunmaktadır (Şekil 15). Birinci gruptaki deneklerin \%16'sı ve ikinci gruptakilerin \%20'si pandemiyle birlikte balkonlarında daha çok zaman geçirmeye başladıklarını belirtmiştir.

Denekler pandemide konutlarıyla ilgili yaşadıkları mekânsal problemlerin içine, apartmandaki ortak kullanım alanlarında yaşadıkları sorunları da dahil etmiştir.
"Asansör sorunu" parametresi, anketteki diğer bir soru olan "Apartmandaki konutunuzun dışındaki asansör, bina giriş kapısı vb. ortak kullanım alanlarında pandemi nedeniyle tedirginlik duydunuz mu? (Konutunuz eğer apartman dairesiyse, aşağıdaki soruyu cevaplayınız.)" sorusuna verilen cevaplarla birlikte analiz edilmiştir. Buna göre, birinci gruptaki deneklerin \%66'sı ve ikinci gruptaki deneklerin \%76'sı ortak kullanım alanlarından tedirginlik duyduklarını belirtmiştir. Birinci gruptan 7 , ikinci gruptan 3 kişi müstakil evlerde yaşamaları nedeniyle bu soruya yanıt vermemiştir.

Denekler bu sorunlar haricinde havalandırma sorunları, doğal ışık yetersizliği, doğal ışık fazlalığı, yanlış mobilya seçimi ve genel tasarım hataları gibi sorunlardan da bahsetmiştir. Son olarak da, birinci gruptakilerin \%24'ü konutlarında herhangi bir mekânsal problem yaşamadıklarını belirtmiştir. Bu parametre de, deneklerin konutlarının pandemi sürecini daha kolay/daha sıkıntılı yaşamalarında etken rol oynama durumunun ölçüldüğü sorunun yanıtlarıyla beraber incelenmesi amaçlanmıştır. Birinci gruptakilerin \%42'si ve ikinci gruptakilerin \%30'unun konut mekânlarının pandemi süreci üzerinde olumlu ya da olumsuz bir etkisi olmadığını belirtirken; birinci gruptakilerin \%46'sı ve ikinci gruptakilerin \%60' ı konutlarının süreci daha kolay geçirmelerini sağladığını belirtmiştir (Şekil 16). Tüm bireylerin sağlıklı olduğu konutlarda yaşayan deneklerin, konut mekânlarından daha memnun oldukları görülmektedir. Deneklere ayrıca pandemiyle birlikte konuta dair yeni mekânsal ölçütlerin oluşup oluşmadığı da sorulmuştur. Birinci gruptakilerin \%30'u ve ikinci gruptakilerin \%42'si, konuta dair yeni mekânsal ölçütlerinin oluştuğunu belirtmiştir. 


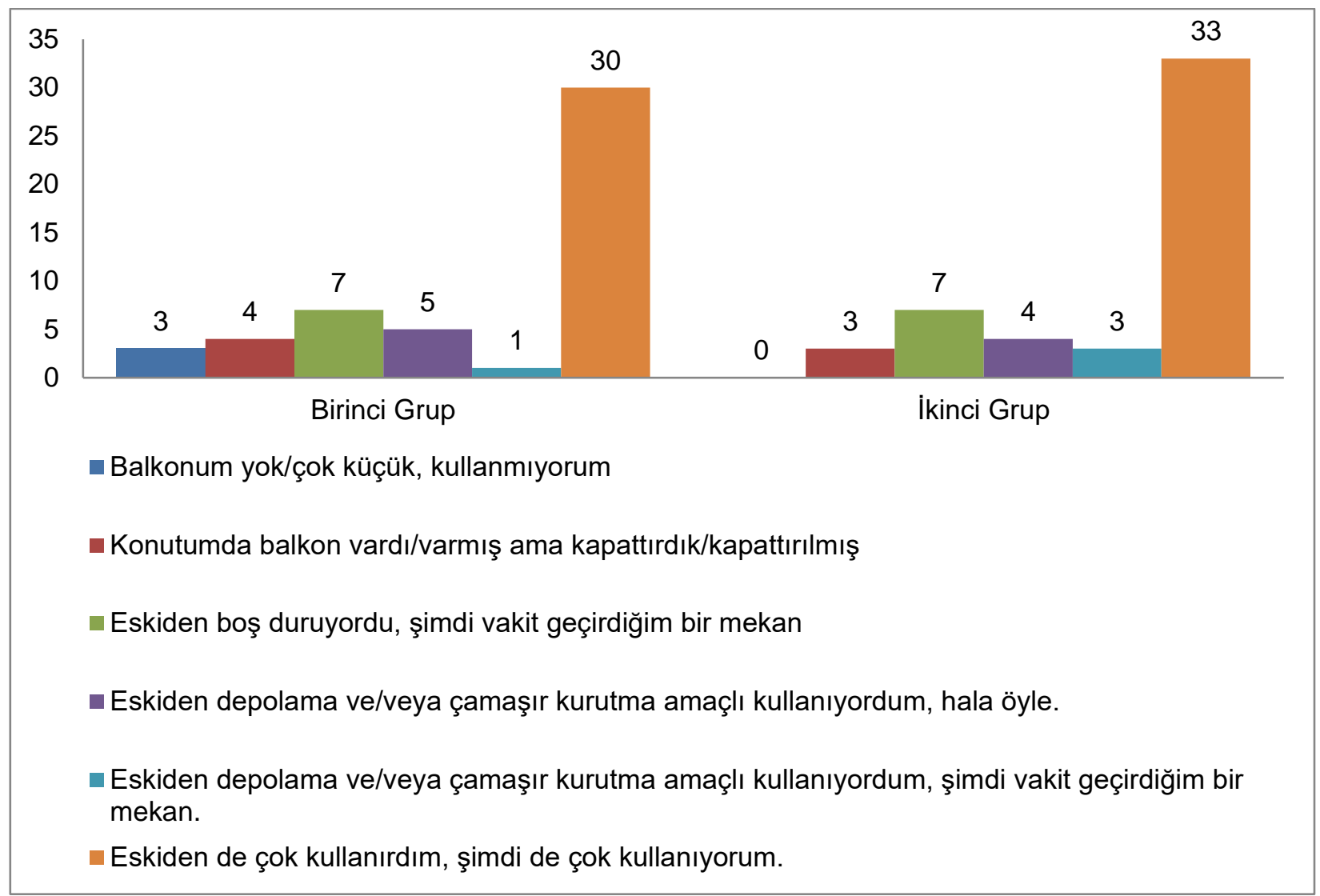

Şekil 15. Deneklerin balkon mekânını pandemi öncesi ve sonrasında kullanımları durumu

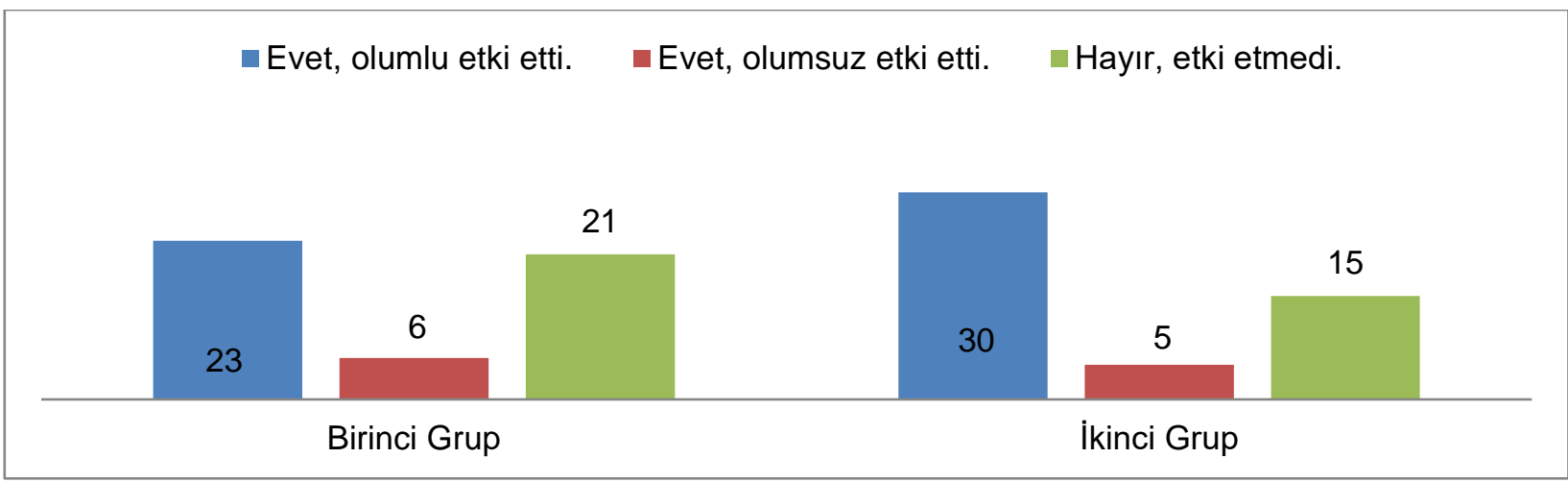

Şekil 16. Konutun deneklerin pandemi sürecini daha kolay/daha sıkıntılı yaşamalarında etken rol oynama durumu

\section{SONUÇLAR}

Antalya ölçeğinde yapılan bu çalışmada, pandemi sürecinde tümünün sağlıklı olduğu ve en az bir hasta bireyin yaşadığı konutlardaki deneklerin konut deneyimleri karşılaştırılmıştır. Bu bağlamda bahçe intiyacı sağlıklı denek grubunda, havalandırma ve yetersiz depolama alanı sorunları ise sağlık sorunu olan denek grubunda daha çok belirtilmiştir. Konut memnuniyetine gelindiğinde ise, sağlık sorunu olan denek grubunun, tamamı sağlıklı bireylerden oluşan denek grubuna göre konutlarından daha çok memnun olduğu görülmüştür. Bunun nedeni, belki sağlık sorunu olan gruptaki bireylerin konut alma/kiralama işlemini yaparken, sağlık koşullarını göz önüne alarak bir seçim yapmış olmaları olabilecektir. Tamamı sağlıklı grup ise ilk defa pandemiyle birlikte bunu öncelik haline getirmiş olabilir.

Yetersiz alan, yetersiz çalışma alanı ve yetersiz balkon mekânı iki denek grubunda da yakın oranda sorun olarak görülmüş ve belirtilmiştir. Ayrıca, giriş mekânındaki 
alan yetersizliği ve mekan organizasyon eksikliği iki örneklem grubunda da en yüksek orandaki sorun olarak belirtilmiştir. Bu çalışma, yalnızca fiziksel olarak hasta olan bireyleri içermektedir. Gelecek çalışmalarda pandemi nedeniyle konutlara kapanma sürecinin mental olarak da zorlayıcı ve yıpratıcı olması göz önünde bulundurularak zihinsel ve psikolojik rahatsızlıkları olanlar ve sağlıklı bireylerin konut deneyimine dair bir karşılaştırmanın yapılması literatür açısından yararlı olacaktır.

\section{KAYNAKLAR}

Altınyıldız Artun, N., Ojalvo, R. (2018). Arzu Mimarlığı, İletişim Yayınları, $318 \mathrm{~s}$.

Arın Ensarioğlu, S. (2020). Pandemi Sürecinin "Evrensel Tasarım" İlkelerine Etkileri. Journal of Social and Humanities Sciences Research, 7(55): 1673-1680.

Durukan, A., Öztürk, Ö.B. (2020). Küresel Salgından İç Mimari Çıkarımlar: Boşu Tasarlamak ve Boşluk Körlüğünden Kurtulmak. Journal of Social and Humanities Sciences Research, 7(56): 1962-1968.

Genç, Ö. (2011). Kara Ölüm: 1348 Veba Salgını ve Ortaçağ Avrupa'sına Etkileri. Journal of History School, 123-150.

Gürel, H., Ülkü, S. (2007). Bitişik Nizamlı Villa Tipi Konutlarda Yapısal Konfor Koşulları Üzerine Bir Araştırma. Uludağ Üniversitesi Mühendislik-Mimarlık Fakültesi Dergisi, 12(2): 97-107.
Harari, Y.N. (2019). HOMO DEUS yarının kısa bir tarihi, Kolektif Kitap, İstanbul, $453 \mathrm{~s}$.

Lefebvre, H. (2014). Mekanın Üretimi, Sel Yayıncılık, 447 s.

Özer, B. (1987). Yorumlar Resim Heykel Mimarlık, Mimar Sinan Üniversitesi Yayını, $293 \mathrm{~s}$.

Parıldar, H. (2020). Tarihte Bulaşıcı Hastalık Salgınları. Tepecik Eğitim ve Araştırma Hastanesi Dergisi, (30):19-26.

Temel, M.K. (2012). 1918 Grip Pandemisi. İstanbul Üniversitesi Sağlik Bilimleri Enstitüsü Yüksek Lisans Tezi, İstanbul.

URL-1 (2020). https://www.who.int/emergencies/diseases/novel-coronavirus-2019/question-and-answers-hub/q-a-detail/q-a-coronaviruses (Erişim Tarihi: 18.11.2020).

URL-2 (2020). https://newsroom.unsw.edu.au/news/health/covid-19-double-blow-chronic-disease-patients, (Erişim Tarihi: 29.11.2020).

URL-3 (2021). https://www.hurriyet.com.tr/galeri-sokagacikma-yasagi-genelgesine-gore-kronik-hastalar-ne-zaman-sokaga-cikabilecek-41518267/1 (Erişim Tarihi: 26.02.2021).

Yaşar K.K., Pehlivanoğlu, F., Çiçek, G., Şengöz, G. (2011). 21. Yüzyılın İlk Pandemisi H1N1: Kesin Tanılı Hastaneye Yatırılan Olguların Değerlendirilmesi. Fırat Tıp Dergisi, 16(3): 132-136.

Zeydan, İ., Gürbüz, A. (2020). 21. Yüzyıldaki Pandemiler ve Turizm Sektörüne Etkileri. In Econder $20203^{\text {rd }}$ International Economics, Business and Social Sciences Congress, 125-131. 